\title{
Seasonal diving behaviour and feeding rhythms of green turtles at Mayotte Island
}

\author{
Katia Ballorain ${ }^{1,2,3, *}$, Jérôme Bourjea ${ }^{4}$, Stéphane Ciccione ${ }^{5}$, Akiko Kato ${ }^{1,2}$, \\ Nicolas Hanuise $^{1,2,6}$, Manfred Enstipp ${ }^{1,2}$, Sabrina Fossette ${ }^{7}$, Jean-Yves Georges ${ }^{1,2}$ \\ ${ }^{1}$ Université de Strasbourg, IPHC, 23 rue Becquerel, 67087 Strasbourg, France \\ ${ }^{2}$ CNRS, UMR 7178, 67037 Strasbourg, France \\ ${ }^{3}$ Université de La Réunion, 15 Avenue René Cassin, BP 7151, 97715 Saint-Denis Messag Cedex 9, La Réunion, France \\ ${ }^{4}$ Institut Français de Recherche pour l'Exploitation de la Mer, Délégation de La Réunion, Rue Jean Bertho, BP 60, \\ 97822 Le Port Cedex, La Réunion, France \\ ${ }^{5}$ Kelonia, l'Observatoire des tortues marines de La Réunion, 46 rue du Général de Gaulle, 97436 Saint Leu, La Réunion, \\ France \\ ${ }^{6}$ Centre d'Études Biologiques de Chizé, CEBC-CNRS UPR 1934, 79360 Villiers en Bois, France \\ ${ }^{7}$ Biological Sciences, College of Science, Swansea University, Singleton Park, Swansea SA2 8PP, UK
}

\begin{abstract}
In long-distance migratory marine species foraging behaviour remains particularly difficult to study even though it has important consequences for individual life history. Indeed, studies assessing concurrent dive patterns and feeding behaviour remain rare. We investigated the daily and seasonal feeding rhythms of green turtles Chelonia mydas on a coastal seagrass meadow at Mayotte, in the South Western Indian Ocean. Between 2005 and 2008, the behaviour of 19 green turtles (body mass: 86.8 to $134.0 \mathrm{~kg}$ ) was recorded using electronic time-temperature-depth recorders, concurrently validated by direct in-water observations. Additionally, fast-acquisition global positioning system units were deployed on 3 of these turtles. Green turtles showed a high fidelity to the foraging site and conducted predominately flat-bottom dives, in accordance with both local bathymetry and tidal regime. On a daily basis, 2 main dive categories were identified: shortshallow foraging dives (mean $\pm \mathrm{SE}$ : $6.0 \pm 0.0 \mathrm{~min}$ for $2.0 \pm 0.0 \mathrm{~m}$ ) occurred during the day on the seagrass meadow, and long-deep resting dives $(50.9 \pm 19.0 \mathrm{~min}$ for $10.3 \pm 1.4 \mathrm{~m})$ occurred at night in coral and rocky areas. On a seasonal basis, mean dive duration increased from summer to winter (from $9.5 \pm 0.5$ to $15.7 \pm 1.1 \mathrm{~min}$ ) and was negatively correlated with seasonal water temperature (range: $25.7^{\circ} \mathrm{C}$ in winter to $29.3^{\circ} \mathrm{C}$ in summer). However, the daily foraging duration $\left(\sim 11 \mathrm{~h} \mathrm{~d}^{-1}\right)$ did not vary significantly with season. Investigating green turtle foraging patterns is crucial for an understanding of their contribution to coastal ecosystem functioning.
\end{abstract}

KEY WORDS: Sea turtles - Foraging behaviour - Diving behaviour - Diel pattern - Seasonal pattern $\cdot$ Seagrass

Resale or republication not permitted without written consent of the publisher

\section{INTRODUCTION}

The understanding of ecosystem functioning requires the assessment of the trophic ecology of animal populations in their natural environment. One key step in this endeavour consists of gathering funda- mental knowledge about individual physiology, behaviour, and ecology for estimating time and energy budgets, which then have to be further integrated at the population level. Time budgets can be derived from estimated feeding rhythms (Stephens \& Krebs 1986). Feeding rhythms primarily depend on individ- 
ual physiological needs and constraints but also on environmental and trophic conditions encountered by individuals (Wikelski \& Hau 1995, Heilman \& Spieler 1999, Nielson 1999, Klein et al. 2006). In air-breathing divers, feeding patterns are intrinsically linked to dive patterns. With technological advances in recent years (e.g. telemetry, biologging), dive patterns of marine animals have been investigated extensively (RopertCoudert \& Wilson 2005, Hooker et al. 2007, Bograd et al. 2010). Dive data are often used to infer specific physiological, behavioural, or ecological functions of dives according to classification analyses (Lesage et al. 1999, Thums et al. 2008). Only in recent years have researchers started to record actual foraging behaviour concurrently with dive parameters (Heithaus et al. 2002, Davis et al. 2003, Seminoff et al. 2006, Schofield et al. 2006, Heaslip et al. 2012, Takahashi et al. 2008). Hence, most of our knowledge regarding the biology of diving species remains incomplete, leading to a biased understanding of their ecology and contribution to ecosystem functioning.

Sea turtles are widely distributed in tropical and temperate waters, and often undergo long-distance migrations. Their reproduction primarily relies on body reserves stored during the time spent on their foraging grounds prior to the nesting season, during which they are commonly considered as not feeding (Miller 1997, but see Myers \& Hays 2006, Fossette et al. 2008, 2009, Casey et al. 2010). Accordingly, investigating the foraging behaviour of sea turtles is critical for a better understanding of their biology, but also for conservation issues facing this endangered species. Yet, given the remoteness and poor accessibility of their feeding sites, the assessment of sea turtles' diving behaviour often relies on satellite-relayed data (Godley et al. 2008), not incorporating concurrent detailed investigation of the actual feeding activity. Thus, to date, most studies specifically investigating the fine-scale diving patterns of sea turtles have focused on the nesting season, when breeding females are easier to capture and monitor using electronic recording devices such as TemperatureTime-Depth Recorders (hereafter referred to as TDRs) (e.g. Eckert et al. 1986, Hochscheid et al. 1999). Therefore, our understanding of the diving and foraging behaviour and ecology of sea turtles in their foraging areas remains limited.

In foraging areas, the diving behaviour of TDR-instrumented sea turtles has been investigated in hawksbill Eretmochelys imbricata (van Dam \& Diez 1997, Blumenthal et al. 2009, Witt et al. 2010b), loggerhead Caretta caretta (Houghton et al. 2000, Okuyama et al. 2009, Thomson et al. 2012), olive ridley Lepi- dochelys olivacea (McMahon et al. 2007), leatherback Dermochelys coriacea (James et al. 2006, Jonsen et al. 2007, Heaslip et al. 2012) and green turtles Chelonia mydas (Heithaus et al. 2002, Southwood et al. 2003, Makowski et al. 2006, Seminoff et al. 2006, Hazel et al. 2009, Thomson et al. 2012). The green turtle is the only sea turtle that feeds primarily on shallow coastal seagrass and algae meadows (Bjorndal 1997), a habit that makes it relatively accessible in comparison with other species. Hence, the green turtle is a good model species to investigate the foraging behaviour of sea turtles. To date, however, only a few studies have investigated the feeding behaviour of green turtles in great detail. Besides conventional TDRs, these studies deployed a number of additional tools in parallel. For example, acoustic tracking of TDR-equipped green turtles feeding on algae revealed a diel diving and foraging pattern that was associated with a differential habitat use between day and night (Rice et al. 2000, Makowski et al. 2006). Video cameras concurrently deployed with dive recorders showed that in green turtles, a given dive shape can be associated with different behaviours and cautioned against the use of dive shapes as an index of feeding activity (Heithaus et al. 2002, Seminoff et al. 2006). The assessment of the actual behaviour associated with a given dive shape is crucial, however, especially since the diving behaviour of green turtles undergoes seasonal changes, which so far have been mainly discussed in relation to their ectothermic physiology (Spotila et al. 1997, Seebacher \& Franklin 2005). For example, juvenile and adult green turtles in Western Australia and adult green turtles in the Mediterranean Sea have been reported to perform longer dives in winter than in summer (e.g. Southwood et al. 2003, Broderick et al. 2007, Hazel et al. 2009). Apart from documented cases of green turtles not feeding during their over-wintering period (Felger et al. 1976, Godley et al. 2002, Broderick et al. 2007), it is not known whether seasonal thermal variations induce changes in the feeding rhythm of green turtles while on the foraging grounds. This underscores the need for an integrated approach to assess the function of recorded dives in relation to environmental conditions, so that year-round feeding time budgets can be established.

Here, we monitored the fine-scale diving behaviour and associated feeding activity of green turtles exploiting a seagrass meadow year-round at Mayotte Island (South Western Indian Ocean-SWIO). We combined the use of conventional time depth recorders and Fastloc-GPS tracking units with direct focal observations to investigate their daily and seasonal feeding rhythms in relation to habitat use. 


\section{MATERIALS AND METHODS}

Fieldwork was conducted between 2005 and 2008 in the Bay of N'Gouja, located on the southern coast of Mayotte Island $\left(12^{\circ} 58^{\prime} \mathrm{S}, 45^{\circ} 05^{\prime} \mathrm{E}\right)$, Comoros Archipelago, SWIO. Mayotte hosts important nesting and feeding areas for distinct populations of green turtles (Roos et al. 2005, Bourjea et al. 2007a,b, Ballorain et al. 2010). Given the effort of local conservation programs and significant tourist activities in the Bay of N'Gouja (Ballorain \& Nivert 2009), most green turtles that feed in the bay have been individually tagged and are accustomed to divers. This provides good conditions to directly observe and manipulate feeding green turtles, while minimizing disturbance.

$\mathrm{N}^{\prime}$ Gouja hosts a multi-species seagrass meadow in the inner fringing reef flat of the bay, where 8 out of the 11 seagrass species inventoried around Mayotte occur (Ballorain et al. 2010). The seagrass bottom drops progressively from the shore to a coral reef on the inner reef slope, never exceeding $4 \mathrm{~m}$ depth, even at the highest tide level. Depending on the tides, the seagrass meadow becomes fully or partially exposed twice within a $24 \mathrm{~h}$ period (Fig. 1).

\section{Dive recorder deployments}

Between 2005 and 2008, a total of 19 green turtles were instrumented with different electronic TDRs (Table S1 in the supplement at www.int-res.com/ articles/suppl/m483p289_supp.pdf). All TDRs included pressure and temperature sensors, recording dive depth (0.05 to $0.10 \mathrm{~m}$ resolution) and water temperature ( \pm 0.018 to $0.050^{\circ} \mathrm{C}$ resolution) every 1 , 2 , or $4 \mathrm{sec}$, which resulted in a deployment duration that ranged from 3 to $24 \mathrm{~d}$ before the memory was filled. We used 3 different models of TDRs: (1) PTD

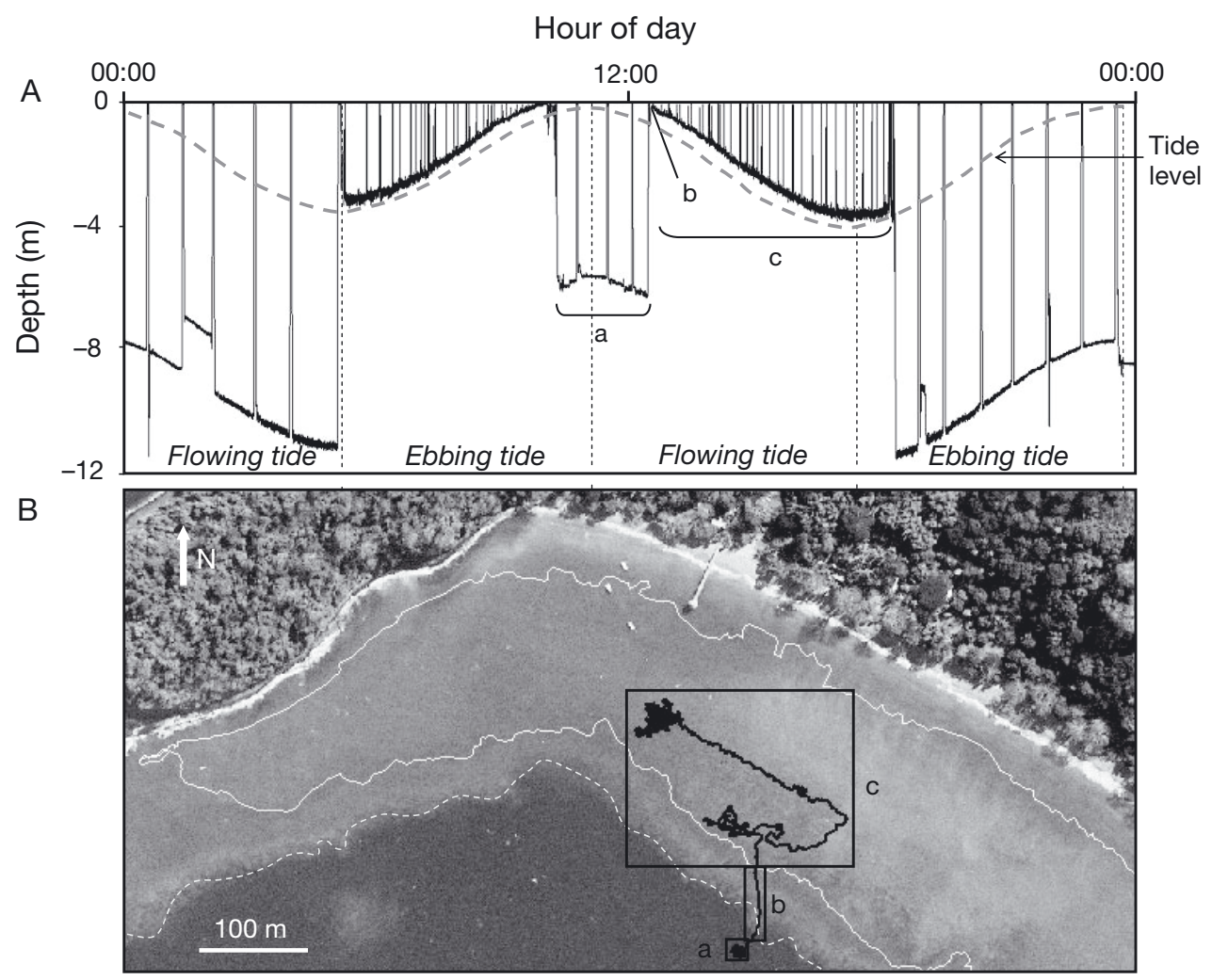

Fig. 1. Chelonia mydas. Example of data collected on the individual CM5 concurrently equipped with a Temperature-TimeDepth Recorder (TDR) and tracked by a snorkeler holding a GPS at N'Gouja Bay, Mayotte Island. (A) TDR data show the $24 \mathrm{~h}$ dive profile on 19 April 2007 (solid lines: dive depth, dashed lines: tide conditions). (B) Aerial view of N'Gouja Bay and superimposed GPS track obtained from 10:16 h to 17:46 h. N'Gouja Bay consists of a shallow (<4 m depth), nearshore multispecies seagrass meadow (outlined by white line), which is separated from a deeper (10 to $20 \mathrm{~m}$ depth) sandy seafloor by an inner fringing reef slope (dotted white line). During the $7.5 \mathrm{~h}$ of tracking, CM5 was (a) first observed resting on a rocky spot for 4 deep and long type D dives (at low tide of $\sim 0.4 \mathrm{~m}$ ), before (b) commuting with 2 short and shallow $(<0.8 \mathrm{~m})$ travelling dives towards the seagrass meadow, where (c) it foraged during 39 short and shallow dives ( $\mathrm{n}=30$ type A dives, $\mathrm{n}=9<0.8 \mathrm{~m}$ dives). Note the effects of tidal rhythm on the pattern of habitat use and on the maximum depth reach for successive dives occurring in a given restricted area 
(earth\&OCEAN Technologies; size: $75 \times 35 \mathrm{~mm}$, mass in air: $23 \mathrm{~g}$ ); (2) W190L-PD2GT (Little Leonardo; size: $114 \times 21 \mathrm{~mm}$, mass in air: $70 \mathrm{~g}$ ); and (3) M190L-D2GT (Little Leonardo; size: $53 \times 15 \mathrm{~mm}$, mass in air: $18 \mathrm{~g}$ ). We used the following criteria to select green turtles for instrumentation: (1) easily identifiable because of the individual flipper tag, (2) regularly encountered during snorkelling surveys in the study area, and (3) accustomed to the proximity of snorkelers. Selected individuals were captured by hand underwater and moved to the beach. Turtles were then placed in a shaded wooden enclosure. We measured the curved carapace length (CCL: along the midline of the shell, from the nuchal scute of the carapace to the end of one caudal scute) using a flexible measuring tape $( \pm 0.5 \mathrm{~cm})$. Body mass was obtained using an electronic spring balance ( $600 \pm 0.2 \mathrm{~kg}$; Kern). TDRs were fixed on the carapace using 2 different attachment techniques: (1) in 2005 and 2006 (for 7 deployments, $\mathrm{n}=7$ turtles, see Table S1 in the supplement), TDRs were fixed to the underside of the rear post-marginal scales of the carapace. We used 2 nylon ties that passed through four $0.5 \mathrm{~cm}$ diameter holes, drilled by hand, to attach the logger; (2) in 2007 and 2008 (for 14 deployments, $\mathrm{n}=13$ turtles, see Table S1), TDRs were fixed to the second vertebral scute of the carapace. Two nylon ties were used to anchor the logger to a steel and galvanized wire mesh that had been set on the carapace with fast setting epoxy (Pure-2 K, Powers Fasteners). This second technique facilitated detachment and re-attachment of the TDR underwater, without having to capture the turtle, which enabled successive deployments of instruments on the same individual (Table S1). Snorkelling observations revealed that turtles performed foraging dives immediately following release, suggesting minimal postrelease stress. Daily searches for instrumented green turtles were conducted throughout the study site (including seagrass bed and adjacent rocky area and coral reef; Fig. 1) during 2 to $6 \mathrm{~h}$ snorkelling patrols. Once an instrumented turtle was encountered, its behaviour was monitored through direct underwater observation (see below).

\section{Dive data analyses}

Of the 13 green turtles equipped using the epoxy TDR-attachment technique, 3 ind. were equipped for 2 successive periods. For the analyses, we considered 2 successive deployments as a single TDRdeployment (Table S1). Overall, 2 ind. were equipped in 2 different years and the recordings were included in the analysis as independent TDRdeployments to take into account the putative different trophic conditions (Table S1). In total, we analysed 21 TDR-deployments for 19 green turtles. Data were analysed using IGOR Pro (Version 5.0; WaveMetrics). Given the precision of the TDR deployed, all dives with a maximum dive depth $<0.8 \mathrm{~m}$ were not distinguishable on the initial data set and were excluded from the analysis. For each dive $>0.8 \mathrm{~m}$, we recorded the following parameters: start and end time of the dive; maximum depth reached; descent, bottom, and ascent duration; descent and ascent speed; post-dive surface interval duration. Here, post-dive surface interval duration is defined as the time spent at a depth $<0.8 \mathrm{~m}$. For each bottom phase, the depth amplitude and the number of vertical undulations (hereafter referred to as 'wiggles', see Fossette et al. 2007) were also noted. As the deployment duration, and hence the total number of dives, varied between individuals, we calculated mean values for all dive parameters (grand means were calculated from the means of individuals).

We used a generalized linear mixed models (GLMMs) to investigate the effects of TDR model (PTD, PD2GT, D2GT), sampling interval (1, 2, 4 sec), year (from 2005 to 2008), season (summer, winter), diel rhythm (day, night), and turtle curved carapace length (CCL) on turtle dive depth and dive duration. Since sex determination is tentative for mediumsized individuals (CCL 85 to $90 \mathrm{~cm}$ ), we did not include sex as a factor in our model. TDR model, sampling interval, year, season, diel rhythm, and CCL were considered as fixed variables, while TDRdeployment was considered as a random variable to account for repeated sampling. To investigate diurnal dive rhythms, sunrise and sunset hours were set from field observations to 06:00 $\mathrm{h}$ and 18:00 $\mathrm{h}$ (local time $=$ GMT $+3 \mathrm{~h}$ ), respectively. GLMM selection followed a stepwise backward elimination procedure, where non-significant variables were successively removed to produce the most parsimonious model. Diving effort was studied using 3 parameters: (1) dive rate $=$ mean number of dives per hour, (2) dive time $=$ sum of the duration of all dives performed per hour, and (3) hourly vertical diving distance = cumulated vertical dive distance travelled per hour. Finally, in order to identify dive types, a principal component analysis (PCA) and a hierarchical cluster analysis (HCA) were successively performed on all dives using SPAD 3.01 (CISIA, France). The 10 following dive parameters were subjected to the PCA using the Copri procedure: dive depth; dive duration; durations of the descent, bottom, and ascent phases; 
depth at the beginning and at the end of the bottom phase; number of wiggles and depth amplitude at the bottom phase; and post-dive surface interval duration. We then applied the HCA using the Parti-decla procedure to determine the appropriate number of dive types and their characteristics.

Standard statistical analyses were conducted using Systat 9.0 (SPSS) and GLMMs were performed with R 2.15 (package 'nlme'; Pinheiro et al. 2012) assuming a Gaussian distribution. Normality of the residuals was tested using the Shapiro-Wilk test, or by visual inspection of residual histograms for large samples ( $>5000)$. Values were expressed as means \pm standard error (SE). Significance was accepted when p-value $<0.05$.

\section{Focal observations and tracking}

Survey patrols were regularly conducted throughout the study site (seagrass bed and adjacent rocky area and coral reef; Fig. 1) to investigate the behaviour of green turtles. During the day, these patrols were conducted by snorkelling (on a daily basis), while during full moon nights snorkelling or scuba diving surveys $(<20 \mathrm{~m})$ were conducted (albeit less frequently). During daily patrols, TDR-instrumented green turtles were opportunistically observed to assess the behavioural functions of dive types identified through PCA and HCA analysis. Every time an instrumented turtle was encountered, time, behaviour (feeding, travelling or resting), and dive patterns (start and end time) were recorded. Records started at the beginning of a complete dive cycle, and only when the turtle did not show any changes in its behaviour. No data was collected when others swimmers (e.g. tourists) approached the study turtle to ensure the turtle's behaviour was not biased. In addition, 1 TDR-instrumented turtle (CM5) was tracked by snorkelling for $7.5 \mathrm{~h}$ using a hand-held global positioning system unit (GPS GeoXTTM handheld Trimble GeoExplorer, ED Electronique, Sainte Savine; precision $\pm 2 \mathrm{~m}$ ), while the individual did not react perceptibly to the presence of the observer.

\section{GPS tracking}

In the winter of 2007, 3 TDR-instrumented turtles (CM11, CM13, and CM14) were equipped with an archival fast-acquisition GPS unit (Fastloc-GPS, FGPS, Sirtrack, Havelock North) (Table S1). FGPS units were fixed to the carapace using the wire mesh technique described above to allow easy detachment underwater at the end of the deployment. During a tracking session, FGPS units were automatically turned on by a saltwater switch when turtles surfaced, and attempted to acquire positioning data from a satellite every $5 \mathrm{~min}$. To increase location accuracy, data processing was conducted only on locations resulting from $\geq 6$ satellites $(30 \pm 30 \mathrm{~m}$ linear error, Hazel 2009, Witt et al. 2010a).

\section{RESULTS}

\section{General dive pattern}

The body size of the 19 turtles ranged from 85 to $104 \mathrm{~cm}$ (CCL), while body mass ranged between 86.8 and $134.0 \mathrm{~kg}$ (Table $\mathrm{S} 1$ in the supplement at www. int-res.com/articles/suppl/m483p289_supp.pdf). Deployment duration lasted from 3 to $24 \mathrm{~d}$, during which a total of 28002 dives $(>0.8 \mathrm{~m}$ ) were recorded (Table 1, Fig. S1 in the supplement.

\section{Dive depth}

For the 21 TDR-deployments, maximum dive depth (mean $\pm \mathrm{SE}$ ) was $3.3 \pm 0.1 \mathrm{~m}$ and hourly vertical diving distance was $32.5 \pm 2.2 \mathrm{~m} \mathrm{~h}^{-1}$ (Table 1). The deepest recorded dive, conducted during daytime in the austral winter, was $67.5 \mathrm{~m}$ deep and $24.1 \mathrm{~min}$ long. Dives to $<4 \mathrm{~m}$ (maximum depth at the seagrass meadow) accounted for $82.6 \%$ of all recorded dives (i.e. $46.7 \%$ of the deployment duration was spent in water shallower than 4 mi Fig. 2). GLMM analysis indicated that maximum dive depth significantly varied with dive duration, CCL, diel rhythm, and season (Fig. 3, Table 2). Maximum dive depth during the daytime was significantly shallower $\left(2.5 \pm 0.1 \mathrm{~m}_{i} \mathrm{n}=21 \mathrm{de}-\right.$ ployments) than those conducted at night $(6.4 \pm$ $0.5 \mathrm{~m} ; \mathrm{n}=21$ deployments). At night, dives conducted in summer were shallower $\left(5.9 \pm 0.6 \mathrm{~m}_{i} \mathrm{n}=13 \mathrm{de}-\right.$ ployments) than those performed in winter $(7.3 \pm$ $0.7 \mathrm{~m}_{i} \mathrm{n}=8$ deployments).

\section{Dive duration}

For the 21 TDR-deployments (all means $\pm \mathrm{SE}$ ), dive duration was $12.6 \pm 3.1 \mathrm{~min}$, with a post-dive surface interval of $0.5 \pm 0.0 \mathrm{~min}$. The longest recorded dive, conducted at night during the austral winter, lasted 


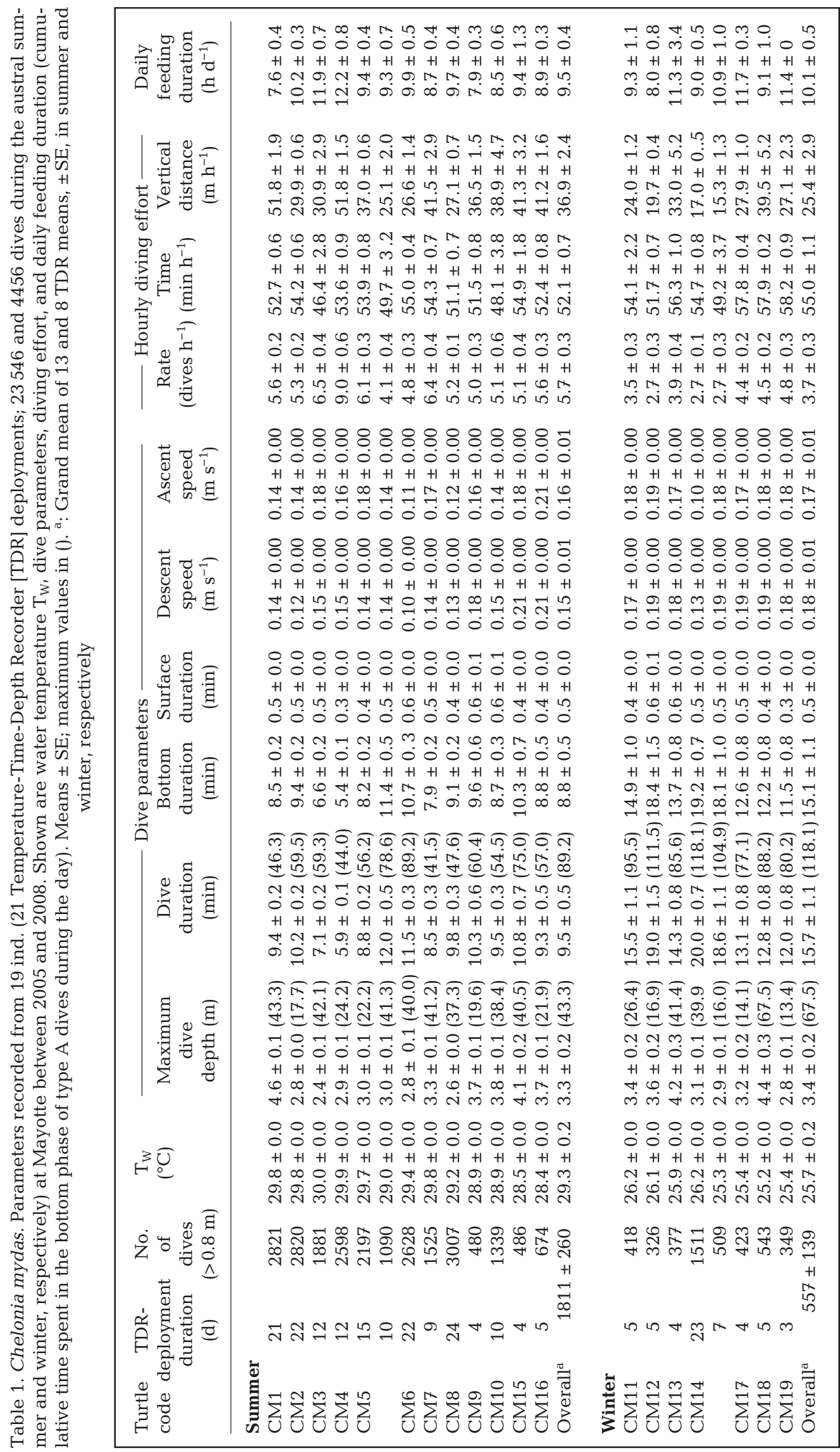




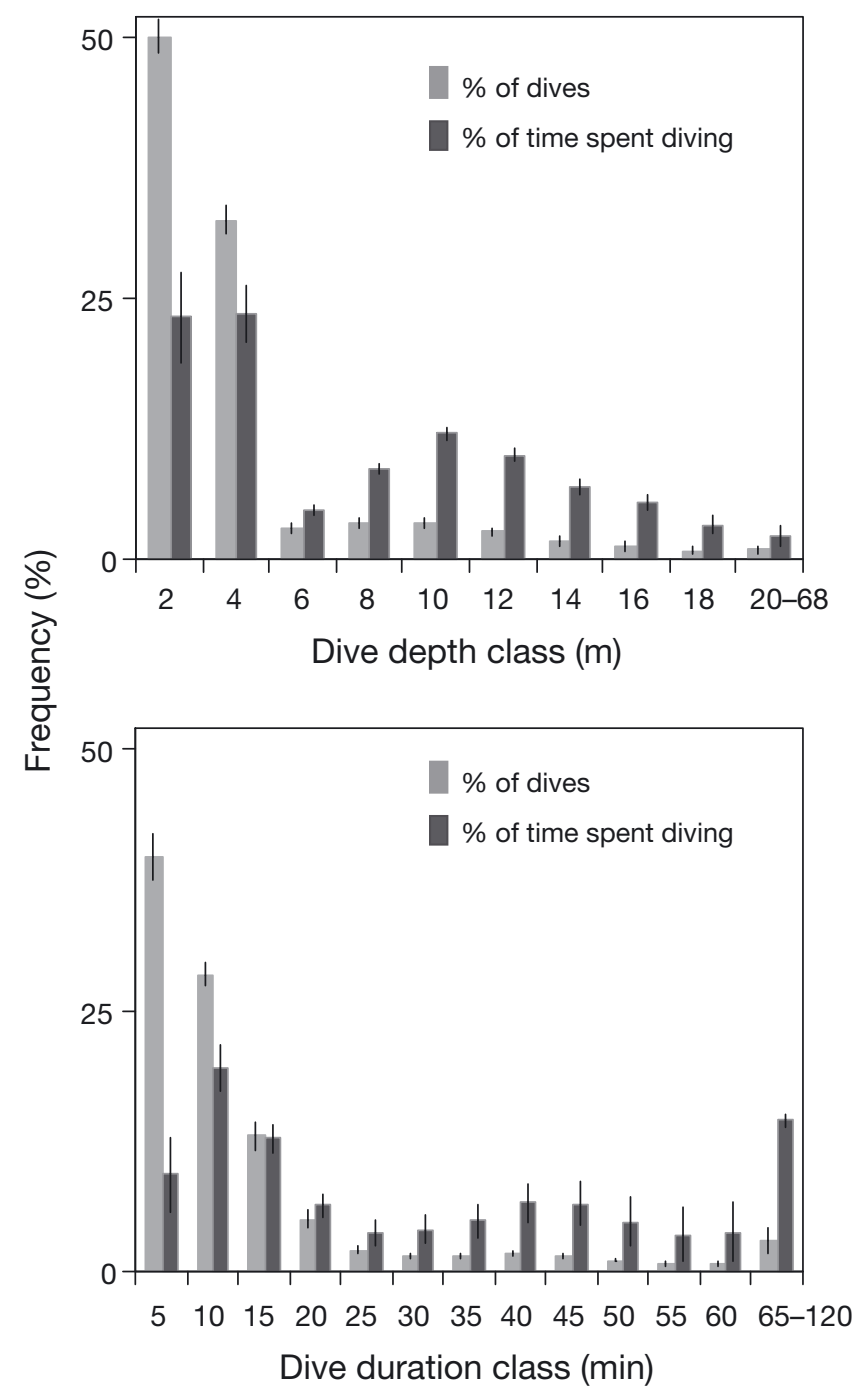

Fig. 2. Chelonia mydas. Frequency distribution of dives by depth and duration classes for 19 ind. (21 TemperatureTime-Depth Recorder deployments; $\mathrm{n}=28002$ dives) at N'Gouja Bay, Mayotte, between 2005 and 2008. Means \pm SE

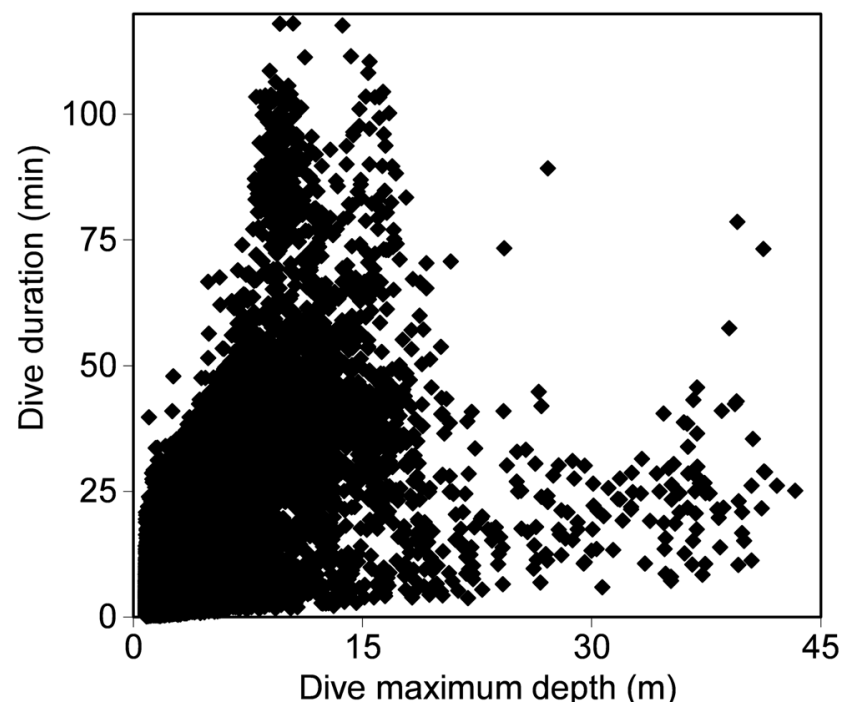

Fig. 3. Chelonia mydas. Relationship between dive duration and maximum dive depth $(\mathrm{n}=28002$ dives) for $19 \mathrm{ind}$. (21 Temperature-Time-Depth Recorder deployments) at N'Gouja Bay, Mayotte, between 2005 and 2008

$118.1 \mathrm{~min}$ for a maximum depth of $10.5 \mathrm{~m}$. Dives lasting $<6 \mathrm{~min}$ and $<28.8 \mathrm{~min}$ represented $50 \%$ and $90 \%$ of all recorded dives, respectively. Turtles spent $51.6 \%$ and $89.1 \%$ of the deployment duration in dives $<25 \mathrm{~min}$ and $<70 \mathrm{~min}$, respectively (Fig. 2). Among the 28002 recorded dives, $95.9 \pm 0.5 \%$ included a bottom phase that corresponded to $83.5 \pm 1.0 \%$ of the dive duration and were characterised by the same steady descent and ascent speeds $\left(0.16 \pm 0.01 \mathrm{~m} \mathrm{~s}^{-1}\right)$. Hourly dive rate was $4.9 \pm 0.3$ dives $\mathrm{h}^{-1}$ and hourly dive time was $53.2 \pm 0.7 \mathrm{~min}^{-1}$. GLMM analysis further indicated that dive duration significantly increased with maximum dive depth (except for rare dives $>20 \mathrm{~m}_{\text {; Fig. }}$ ) and with $\mathrm{CCL}$, and changed significantly with diel rhythm and season (Table 2).

Table 2. Chelonia mydas. Generalized linear mixed model (GLMM) after stepwise backward analysis, performed on all dives ( $\mathrm{n}=28$ 002) and on type A dives only ( $\mathrm{n}=200$ bottom phases) in 19 ind. (21 Temperature-Time-Depth Recorder [TDR] deployments) at Mayotte between 2005 and 2008. CCL: curved carapace length. ${ }^{a}$ : dependent variable, ${ }^{b}$ : co-variable

\begin{tabular}{|c|c|c|c|c|c|c|c|c|c|}
\hline \multirow{3}{*}{ Fixed effect } & \multirow{2}{*}{\multicolumn{6}{|c|}{ 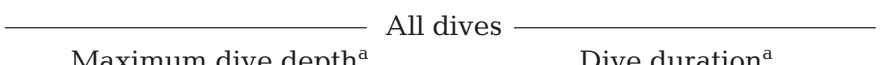 }} & \multirow{2}{*}{\multicolumn{3}{|c|}{$\begin{array}{l}\text { Type A dives } \\
\text { Daily bottom duration }\end{array}$}} \\
\hline & & & & & & & & & \\
\hline & df & $F$ & $\mathrm{p}$ & df & $F$ & $\mathrm{p}$ & $\mathrm{df}$ & $F$ & $\mathrm{p}$ \\
\hline Turtle CCL & 1,18 & 5 & 0.041 & 1,18 & 16 & $<0.001$ & 1,17 & 1.3 & 0.27 \\
\hline Dive duration $^{\mathrm{b}}$ & 1,27978 & 20550 & $<0.001$ & & & & & & \\
\hline Maximum dive depth ${ }^{b}$ & & & & 1,27978 & 24625 & $<0.001$ & & & \\
\hline Diel rhythm & 1,27978 & 56 & $<0.001$ & 1,27978 & 3719 & $<0.001$ & & & \\
\hline Season & 1,18 & 9 & 0.009 & 1,18 & 39 & $<0.001$ & 1,17 & 0.95 & 0.34 \\
\hline Season $\times$ diel rhythm & 1,27978 & 220 & $<0.001$ & 1,27978 & 2142 & $<0.001$ & & & \\
\hline Year & & & & & & & 3,175 & 0.64 & 0.59 \\
\hline TDR model & & & & & & & 2,175 & 0.23 & 0.79 \\
\hline
\end{tabular}


Dives during summer were significantly shorter $(9.5 \pm$ $0.5 \min _{i} \mathrm{n}=13$ deployments) than dives in winter $(15.7 \pm 1.1 \mathrm{~min} ; \mathrm{n}=8$ deployments; Table 1$)$. From winter to summer, water temperature during TDRdeployments ranged from $25.7 \pm 0.2^{\circ} \mathrm{C}(\mathrm{n}=13$ deployments) to $29.3 \pm 0.2^{\circ} \mathrm{C}(\mathrm{n}=8$ deployments; Table 1$)$, and dive duration increased with decreasing temperature $(\mathrm{r}=-0.78, \mathrm{p}<0.001 ; \mathrm{n}=21$ deployments $)$.

Since dive duration and dive depth were correlated, we used a second GLMM to identify the distinct effect of dive duration on (1) dive anticipation (i.e. pre-dive surface interval duration) and (2) dive recovery (i.e. post-dive surface interval duration). The GLMM included pre- and post-dive surface interval duration as a dependant variable, and dive duration as well as the residual values from a linear regression of depth on duration as independent variables (TDR-deployment being considered as a random variable to account for repeated sampling). This second GLMM showed that pre- and post-dive surface interval durations were positively correlated with dive duration $\left(F_{1,25963}=33867.4, \mathrm{p}<0.001\right.$; $F_{1,25963}=81.1, \mathrm{p}<0.001$, respectively) .

\section{Dive types}

The PCA performed on 28002 dives, using the dive parameters described above, identified 2 factors respectively associated with $65.6 \%$ (Factor 1 ) and $15.4 \%$ (Factor 2) of the observed variance. Factor 1 was predominantly associated with dive depth and dive duration, while Factor 2 was mainly associated with the number of wiggles during the bottom phase. The HCA distinguished between 4 different types of dives, mainly based on their depth and bottom duration (named A, B, C, D to facilitate reading: Fig. 4, Table 3): type A dives (85.9\% of recorded dives) represented the shallowest and shortest dives, while type C $(2.4 \%)$ and type D $(11.0 \%)$ dives represented deeper and longer dives. Erratic deep, long and active bounce dives were classified as type B dives, representing $0.8 \%$ of all recorded dives. The time turtles spent in different dive types varied significantly for all TDR-deployments $\left(\chi^{2}{ }_{3}=43.7, \mathrm{p}<0.001\right)$. In total, turtles spent $48.4 \pm 1.6 \%, 1.7 \pm 0.4 \%, 23.8 \pm$ $4.7 \%$, and $26.2 \pm 4.2 \%$ of their time in dives of types A, B, C, and D, respectively.

There was a clear diel pattern in the distribution of dive types $\left(\chi^{2}{ }_{3}=104.4, p>0.001\right.$; Fig. 5): during the day, turtles predominantly spent time in short, shallow type A dives $\left(85.3 \pm 2.1 \%\right.$ of day time, $\chi^{2}{ }_{3}=190.3$, $\mathrm{p}<0.001$ ), while at night they predominantly spent

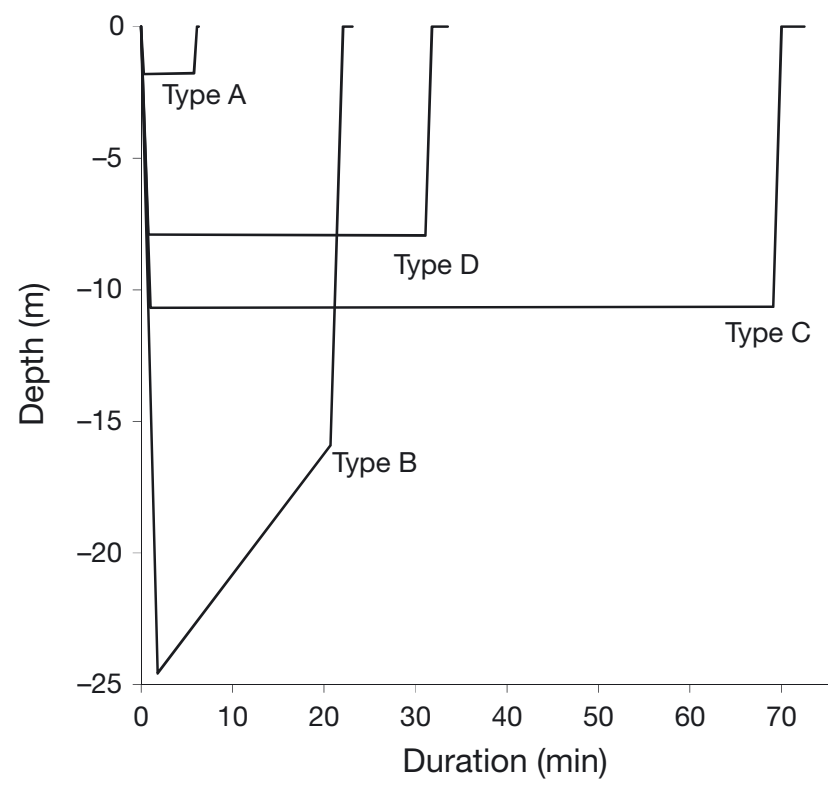

Fig. 4. Chelonia mydas. Schematic representation of the 4 dive types determined by the hierarchical clustering procedure following the principal component analysis $(\mathrm{PCA} \mathrm{n}=$ 28002 dives) for 19 ind. (21 Temperature-Time-Depth Recorder deployments) at N'Gouja Bay, Mayotte, between 2005 and 2008. Dives consisted of a descent phase, a bottom phase (without wiggles), an ascent phase, and a post-dive surface interval

time in long, deep type $\mathrm{C}$ and $\mathrm{D}$ dives $(84.1 \pm 3.3 \%$ of night time, $\left.\chi^{2}{ }_{3}=51.1, \mathrm{p}<0.001\right)$. The distribution of the 4 dive types also varied significantly between seasons $\left(\chi_{3}^{2}=45.42, \mathrm{p}<0.001\right)$ : in summer, turtles spent more time in type A dives $(49.4 \pm 2.4 \%$ of summer time) and type D dives ( $38.5 \pm 4.1 \%$ of summer time), whereas in winter, they spent more time in type A $(45.9 \pm 1.8 \%$ of winter time) and type $\mathrm{C}$ dives $(46.2 \pm 2.5 \%$ of winter time). There were seasonal differences in the predominate dive type at night, but not during the day. Nocturnal dives were mainly assigned to type D in summer $(62.1 \pm 7.6 \%$ of night time, $\chi_{3}^{2}=82.1, \mathrm{p}<0.001$ ) and type $\mathrm{C}$ in winter $\left(84.3 \pm 4.3 \%\right.$ of night time, $\left.\chi^{2}{ }_{3}=189.2, \mathrm{p}<0.001\right)$.

\section{Focal observations and tracking}

Daytime snorkelling observations mostly recorded green turtles feeding on the seagrass bed and, to a lesser extent, resting at the adjacent rocky area or coral reef. At night, turtles were mainly observed resting at the adjacent rocky area or coral reef and, to a lesser extent, feeding on the seagrass bed during full moon nights. The fine-scale behaviour (feeding, travelling, and resting) was recorded for 8 TDR-in- 
Table 3. Chelonia mydas. Parameters for the 4 dive types discriminated from 28002 dives recorded in 19 ind. (21 Temperature-Time-Depth Recorder [TDR] deployments) at Mayotte between 2005 and 2008 (see Fig. 4). Means \pm SE. Frequencies of dive types are expressed in mean frequencies of dive types. ${ }^{a}$ : grand mean of TDR mean values, $\pm \mathrm{SE}$

\begin{tabular}{|c|c|c|c|c|c|}
\hline & & Type A & Tyре B & Type C & Type D \\
\hline \multicolumn{2}{|l|}{ No. of dives } & 24043 & 228 & 659 & 3072 \\
\hline \multicolumn{2}{|c|}{ Dive depth (m) } & $2.0 \pm 0.0$ & $27.6 \pm 0.1$ & $11.6 \pm 0.0$ & $8.9 \pm 0.0$ \\
\hline \multicolumn{2}{|c|}{ Dive duration (min) } & $6.0 \pm 0.0$ & $22.1 \pm 0.1$ & $69.9 \pm 0.1$ & $31.9 \pm 0.1$ \\
\hline \multicolumn{2}{|c|}{ Bottom time ( $\%$ of dive duration) } & $79.5 \pm 0.2$ & $79.0 \pm 0.1$ & $97.2 \pm 0.0$ & $91.9 \pm 0.1$ \\
\hline \multicolumn{2}{|c|}{ Depth amplitude at bottom (m) } & $0.5 \pm 0.0$ & $14.6 \pm 0.1$ & $1.9 \pm 0.0$ & $2.1 \pm 0.0$ \\
\hline \multicolumn{2}{|c|}{ No. of wiggles } & $39.5 \pm 0.3$ & $97.2 \pm 0.7$ & $618.3 \pm 1.7$ & $156.7 \pm 0.6$ \\
\hline \multicolumn{2}{|c|}{ Surface duration (min) } & $0.2 \pm 0.0$ & $1.0 \pm 0.0$ & $2.5 \pm 0.0$ & $1.7 \pm 0.0$ \\
\hline \multicolumn{2}{|c|}{ Descent rate $\left(\mathrm{m} \mathrm{s}^{-1}\right)$} & $0.14 \pm 0.00$ & $0.24 \pm 0.00$ & $0.19 \pm 0.00$ & $0.16 \pm 0.00$ \\
\hline \multicolumn{2}{|c|}{ Ascent rate $\left(\mathrm{m} \mathrm{s}^{-1}\right)$} & $0.14 \pm 0.00$ & $0.19 \pm 0.00$ & $0.21 \pm 0.00$ & $0.20 \pm 0.00$ \\
\hline \multicolumn{6}{|c|}{ Frequency ( $\%$ of dives) } \\
\hline \multirow[t]{2}{*}{ Summer } & Day & $95.2 \pm 0.8$ & $0.9 \pm 0.3$ & $0.1 \pm 0.1$ & $3.8 \pm 07$ \\
\hline & Night & $53.9 \pm 5.4$ & $0.6 \pm 0.3$ & $9.0 \pm 4.0$ & $36.5 \pm 5.7$ \\
\hline \multirow[t]{2}{*}{ Winter } & Day & $95.3 \pm 1.2$ & $0.7 \pm 0.5$ & $0.9 \pm 0.4$ & $3.1 \pm 0.6$ \\
\hline & Night & $44.5 \pm 4.6$ & $0.4 \pm 0.2$ & $47.6 \pm 4.5$ & $7.5 \pm 1.5$ \\
\hline \multirow[t]{2}{*}{ Overall $^{a}$} & Day & $95.2 \pm 0.7$ & $0.9 \pm 0.3$ & $0.4 \pm 0.2$ & $3.5 \pm 0.5$ \\
\hline & Night & $50.3 \pm 3.9$ & $0.5 \pm 0.2$ & $23.7 \pm 5.1$ & $25.4 \pm 4.7$ \\
\hline \multicolumn{6}{|c|}{ Frequency ( $\%$ of time) } \\
\hline \multirow[t]{2}{*}{ Summer } & Day & $84.8 \pm 2.4$ & $3.4 \pm 0.9$ & $0.7 \pm 0.4$ & $11.1 \pm 1.9$ \\
\hline & Night & $18.7 \pm 4.6$ & $0.6 \pm 0.3$ & $18.5 \pm 7.6$ & $62.1 \pm 7.6$ \\
\hline \multirow[t]{2}{*}{ Winter } & Day & $84.1 \pm 4.0$ & $2.1 \pm 1.4$ & $5.8 \pm 2.7$ & $8.0 \pm 1.8$ \\
\hline & Night & $10.0 \pm 3.9$ & $0.3 \pm 0.2$ & $84.3 \pm 4.3$ & $5.4 \pm 1.4$ \\
\hline \multirow[t]{2}{*}{ Overall $^{\mathrm{a}}$} & Day & $84.5 \pm 2.1$ & $2.9 \pm 0.8$ & $2.6 \pm 1.2$ & $9.9 \pm 1.4$ \\
\hline & Night & $15.4 \pm 3.3$ & $0.5 \pm 0.2$ & $43.6 \pm 8.7$ & $40.5 \pm 7.7$ \\
\hline
\end{tabular}

daytime. During our observation time, we never encountered a turtle feeding on seagrass in water $<40 \mathrm{~cm}$ deep. Feeding dives on the seagrass meadow, observed directly during the daytime, lasted $7.8 \pm$ $0.4 \min (\mathrm{n}=89)$, and $12.0 \pm$ $0.9 \min (\mathrm{n}=38)$ in summer and in winter, respectively. All of these dives were independently classified as type A dives with the HCA. Resting dives observed during daytime on the adjacent coral reef lasted $27.3 \pm 4.0 \mathrm{~min}(\mathrm{n}=8$, in summer) and were all independently classified as type D dives. Travelling dives directly observed during the day lasted $3.1 \pm$ $1.0 \min (\mathrm{n}=19)$ and were classified as type $A(n=17)$ but also as type $\mathrm{D}$ dives $(\mathrm{n}=2)$. However, travelling dives consisted mostly in a transition between feeding areas (seagrass meadow) and resting areas (ad-

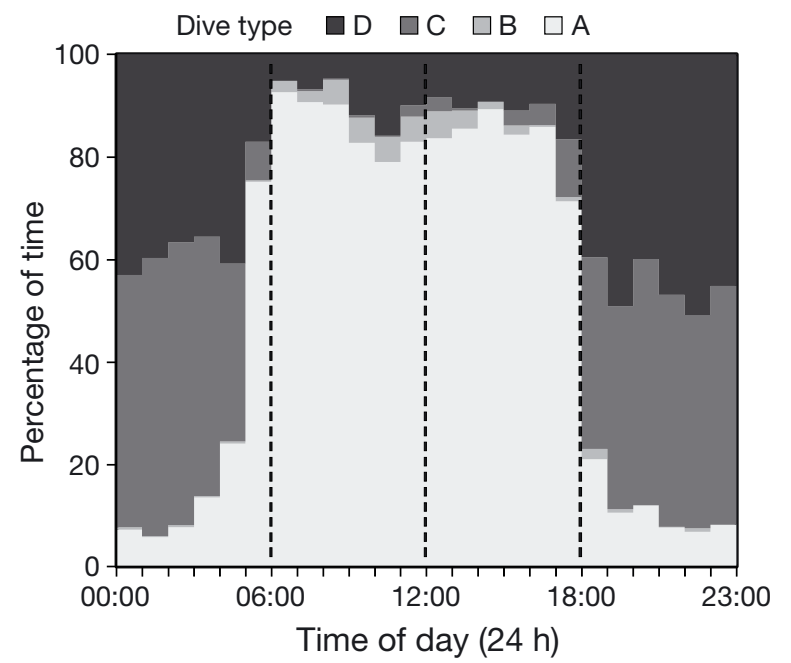

Fig. 5. Chelonia mydas. Diel pattern in the frequency distribution of the 4 different dive types (see Fig. 4) for 19 ind. at N'Gouja Bay, Mayotte, between 2005 and 2008

strumented turtles (Table S1). During analysis, the behaviour recorded during each dive was independently attributed to the dives recorded by the TDR, before independent classification by the HCA (see above). Focal observations allowed monitoring turtles when feeding, resting, and travelling throughout the jacent coral reef) and were erratic in terms of occurrence. In addition, dive depth of observed green turtles was closely linked to tide level on the seagrass meadow (see the general dive pattern illustrated in Fig. 1).

Locations of green turtles instrumented with a FGPS and a TDR were all within the Bay of N'Gouja (Table S1, Fig. 6). Locations were obtained during the surface interval between 2 successive dives, chronologically called pre-dive and post-dive locations (i.e. the interval that is post-dive for one particular dive is pre-dive for the next). We observed the following pattern: $97 \%$ (pre-dive) and 95\% (postdive) of surface events associated with type A dives were located on the inner fringing reef flat, of which the majority was located on the seagrass meadow (91\% pre-dive and $88 \%$ post-dive). All surface events (pre- and post-dive) associated with type B, C, and $\mathrm{D}$ dives were located outside the seagrass meadow (Fig. 6).

\section{DISCUSSION}

Green turtles at N'Gouja spent $\sim 90 \%$ of their time submerged, and mostly conducted very shallow 


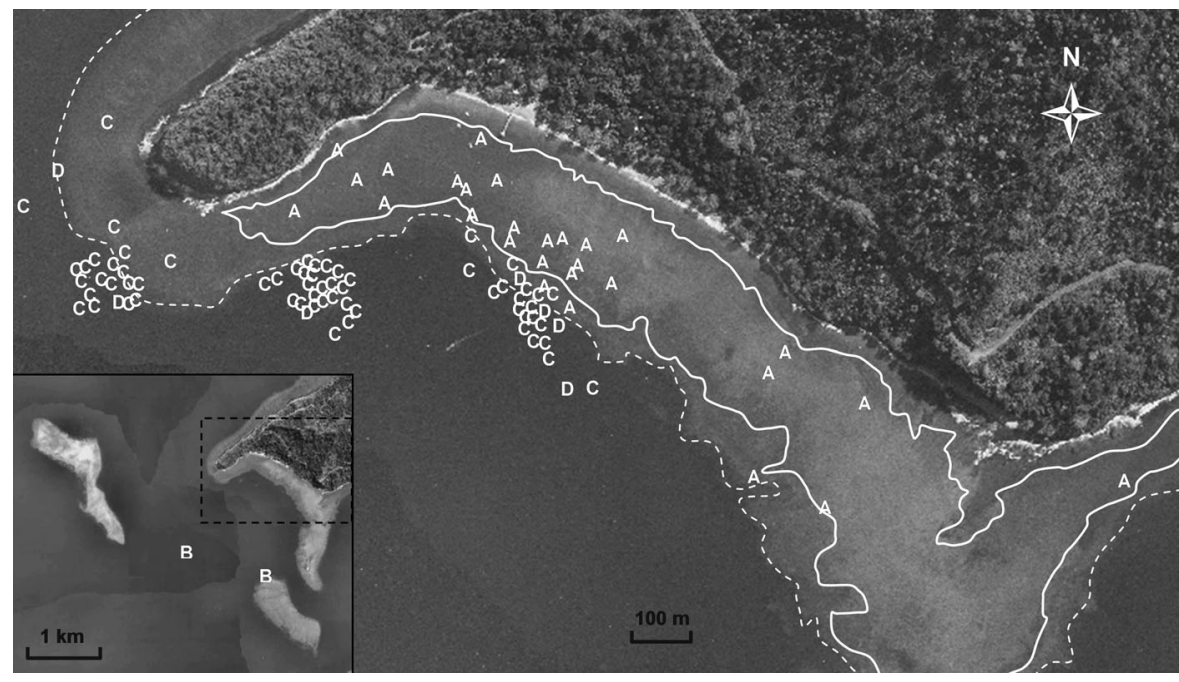

Fig. 6. Chelonia mydas. Locations of 3 ind. instrumented with Fastloc-GPS (FGPS) and TemperatureTime-Depth Recorder (TDR) units at N'Gouja Bay, Mayotte, during winter 2007. The seagrass meadow is outlined by the white line and the deeper bottom area is beyond the fringing reef (white dotted line). Letters correspond to the dive type (see Fig. 4) preceding the surface interval, when GPS location was taken. All surface events associated with type A dives occurred on the seagrass meadow, while all type $\mathrm{C}-\mathrm{D}$ dives occurred outside. Erratic type B dives $(\mathrm{n}=2)$ were conducted further offshore

than other dives (see inset)

$(\sim 3 \mathrm{~m})$ and flat-bottom dives in accordance with the very shallow bathymetry $(<4 \mathrm{~m}$ at high tide on the seagrass meadow) and the tidal regime (Fig. 1). During these flat-bottom dives, commonly performed by green turtles in relatively shallow habitat (Hochscheid et al. 1999, Hays et al. 2000, Thomson et al. 2012), turtles lay immobile or moved slowly above the sea floor with no detectable wiggles. Turtles showed a high fidelity for the study site, and the observed dive patterns are at least partially the result of the spatio-temporal segregation between feeding and resting. Accordingly, turtles displayed a clear diel dive pattern and distinct dive types. Four major types of dives could be discriminated, mostly on the basis of their maximum depth and duration. With the help of our direct observations and the FGPS tracking of TDR-instrumented turtles, we could further attribute 3 main behavioural functions to these different dive types. Short and shallow type A dives (86\% of all recorded dives) were mostly associated with feeding on the seagrass meadow during the day. By contrast, long and deep type $\mathrm{C}$ and $\mathrm{D}$ dives $(13 \%$ of all recorded dives) were mostly associated with resting on the border of the fringing reef during the night, in summer and winter, respectively. We also recorded a few $(<1 \%$ of all recorded dives) deep $(\sim 28 \mathrm{~m})$ and relatively long $(\sim 22 \mathrm{~min})$ dives, that consisted of high amplitude up-and-down movements during the bottom phase $(\sim 15 \mathrm{~m})$. These active bounce dives occurred mostly during the day, and might correspond to interactions with conspecifics or foraging events at the coral reef (e.g. Makowski et al. 2006 for juvenile green turtles feeding on macroalgae and benthic invertebrates on a reef; Blumenthal et al. 2009 for hawksbill turtles foraging on sponges), in the water column, or during benthic exploratory dives (Heithaus et al. 2002, Seminoff et al. 2006). Large green turtles are not exclusively herbivorous and can feed on benthic invertebrates or ctenophores and jellyfish (Bjorndal 1997, Godley et al. 1998, Heithaus et al. 2002, Seminoff et al. 2006, Burkholder 2012). In this context, we made anecdotal observations of green turtles at N'Gouja Bay feeding on algae (e.g. Gracilaria salicornia, Turbinaria sp.), ctenophores, and jellyfish (Physalia). Some green turtles, known to exploit the N'Gouja meadow, were tracked to the barrier reef $(\sim 9 \mathrm{~km}$ away from the fringing reef), supporting the idea that they may occasionally feed in reef areas, away from N'Gouja Bay (K. Ballorain unpubl. data). Nevertheless, we found that green turtles predominantly moved between adjacent foraging and resting areas, which would minimize energetic costs associated with commuting (Makowski et al. 2006).

The relatively short and shallow dives of green turtles at N'Gouja suggest that most dives were aerobic (Costa et al. 2001). This is supported by the relatively short surface durations following dives and the relationship between dive and surface duration we found for our turtles. The time spent breathing at the surface between dives increased with the duration and the depth of the preceding or the following dive, as typically found in air-breathing divers (Wallace et al. 2005 for sea turtles, Wilson \& Quintana 2004 for seabirds, Sparling et al. 2007 for marine mammals). This indicates that for green turtles diving at N'Gouja, most of the surface events were used to recover from the previous dive or to prepare for the dive to follow. Controlling the air volume inspired before diving has previously been reported for a wide range of air- 
breathing diving vertebrates, including sea turtles (e.g. Minamikawa et al. 1997, Hochscheid et al. 2007b, Fossette et al. 2010), seabirds (e.g. Sato et al. 2002, Wilson 2003) and marine mammals (e.g. Biuw et al. 2003). In addition, some of our turtles were occasionally observed basking at the sea surface in shallow water, suggesting that surface events might also be used for thermoregulation (Sapsford \& Van der Riet 1979, Whittow \& Balazs 1982, James et al. 2005, Hochscheid et al. 2010).

Short and shallow type A dives represented 95\% and $85 \%$ of the time spent submerged during daytime in summer and winter, respectively. This indicates that at N'Gouja, feeding is the major activity of green turtles during the day and that most feeding occurs year-round on the seagrass meadow. This is supported by our direct observations, as green turtles were feeding systematically when we encountered them on the N'Gouja Bay seagrass meadow. More importantly, this also indicates that at N'Gouja, green turtles spend a similar proportion of time feeding (i.e. daily bottom duration of type A dives) throughout the year (Table 2) and exert an important pressure as herbivores on seagrass yearround. Type $\mathrm{C}$ and D dives represented $81 \%$ and $90 \%$ of the time spent submerged during the night in summer and winter, respectively. This indicates that green turtles rested mostly during the night, away from the seagrass meadow. Green turtles may also rest during the day, albeit to a much lesser extent, when the seagrass meadow is not accessible at low tide. During the day, turtles rested at cleaning stations (sensu Losey et al. 1994) with symbiotic cleaner fish, located on the rocky and coral spots (Fig. 1). Similar to feeding, the proportion of time spent resting did not vary throughout the year, and dive duration increased with decreasing temperature. Yet the relative contribution of type $\mathrm{C}$ and type D dives varied significantly between seasons. Longer dives (type $\mathrm{C}$ dives, $70 \mathrm{~min}$ ), and intermediate dives (type $\mathrm{D}$ dives, $32 \mathrm{~min}$ ) occurred in winter and summer, respectively. A seasonal shift in dive duration occurred in all TDR-equipped turtles for all dive types, as seasonal mean dive duration increased from 9.5 to $15.7 \mathrm{~min}$ between austral summer and winter. Such seasonal shifts have been reported in sea turtles (e.g. Southwood et al. 2003, Broderick et al. 2007, Hazel et al. 2009) and are interpreted as a consequence of their ectothermic physiology. Since their metabolism is temperature dependent, turtles can increase apnea duration at lower temperatures (Hochscheid et al. 2007a, Wallace \& Jones 2008, Enstipp et al. 2011).
At N'Gouja, green turtles frequented the seagrass meadow for feeding mainly during the daytime, except when water levels were below $40 \mathrm{~cm}$. We also observed turtles feeding on the meadow during full moon nights, but we cannot exclude that feeding might also have occurred during other moon phases. However, typically turtles spent the night resting on the coral reef, as suggested in a previous acoustic tracking study conducted at N'Gouja Bay (Taquet et al. 2006). Numerous studies on immature and mature green turtles, feeding on algae spots or on seagrass meadows, and monitored by acoustic tracking, also reported that turtles exhibited a diurnal foraging pattern (Mendonca 1983, Ogden et al. 1983, Brill et al. 1995, Rice et al. 2000, Makowski et al. 2006, Hazel et al. 2009). Some studies, however, reported a nocturnal foraging pattern related to human activity avoidance (Rice et al. 2000, Seminoff et al. 2002). This suggests that green turtles mainly depend on daytime for feeding. Light-dependent feeding behaviour is almost universal in animals (but see Ward et al. 2008). In marine and herbivorous species, diurnal foraging pattern has been interpreted as a behavioural response to predation risks (e.g. Heithaus \& Dill 2006), tidal rhythm and thermal requirements (e.g. Buttemer \& Dawson 1993, Wikelski \& Hau 1995), or photosynthetic-related nutritional quality of algae (e.g. Zoufal \& Taborsky 1991). In the N'Gouja Bay, tidal constraints are similar for the day and night. Accordingly, green turtles would improve their feeding efficiency during daytime both through a higher body temperature and because of the ability to visually select their food and see potential predators. Further investigations are needed to assess potential diel changes in the nutritional value of seagrasses. Considering that most feeding occurred on the seagrass meadow and during type A dives, our study shows that at N'Gouja, green turtles spent $\sim 9.7 \mathrm{~h}$ per day feeding (i.e. time spent feeding at the bottom phase of type A dives; Table 1) and $10.9 \mathrm{~h}$ per day foraging (i.e. time spent in type A dive cycles: complete type A dives followed by complete postdive surface events). Daily feeding and foraging durations remained more or less constant throughout the year. Our estimate of daily foraging duration is consistent with a recent acoustic survey which found that green turtles exploit the seagrass meadow of N'Gouja between 06:00 $\mathrm{h}$ and 18:00 h (Taquet et al. 2006). Our estimate is also similar to those reported for immature green turtles foraging on algae in Florida (11.4 h; Makowski et al. 2006). However, it differs from the $9 \mathrm{~h}$ foraging time reported for immature green turtles exploiting Pterocladiella capillacea 
pastures in Hawaii and Thalassia testudinum meadows in the Caribbean (Ogden et al. 1983, Williams 1988, Rice et al. 2000). Such differences may result from different seagrass distribution or speciesspecific nutritional quality of the ingested food between sites (Duarte 1992). Differences may also be related to age-specific differences in stomach volume and digestive capacities, or to larger adult turtles potentially feeding for a longer period than younger individuals. Clearly, further investigations with larger sample sizes, including adult and juvenile individuals, are required to assess the determinants of feeding rhythm in sea turtles.

Our study reveals important details concerning the feeding rhythm and habitat use of green turtles in a multi-species seagrass meadow. This is the first step to assess and understand the contribution of this endangered species to coastal ecosystem functioning. Further investigations are now required to estimate their herbivory pressure and show their impact on seagrass habitats. In addition, by documenting the year-round importance of shallow coastal habitats for green turtles in an emerging tourism destination such as Mayotte (Bernardie-Tahir \& Omar 2001), our study contributes to improve conservation measures for this species.

Acknowledgements. We are grateful to the Department of Agriculture and Forestry of Mayotte (DAF), the General Council of Mayotte (CDM) and the Jardin Maoré Hotel for their financial and technical support. We especially thank M. Quillard, D. Chanfi, K. Ahamed, and A. Mari (CDM), R. Rolland, J.P. Arnaud, A. Jamon (DAF), J. Wickel (Lagonia), C. Ducordeau and A. Loricourt (Kelonia), P. Stefanica, F. Bourgeois, B. Fichou (Jardin Maoré Hotel), the National Office for Hunting and Wildlife (ONCFS), the Oulanga na Nyamba Association, and many volunteers for their field assistance. Funding was also provided by the Regional Council of Reunion Island, the European Social Fund (ESF), and the French National Agency of Research (ANR 'ESTVOI project'). Finally, we thank N. Poulin and M. Beaulieu (CNRS IPHC) for their helpful comments on data analyses. This study was carried out under Kelonia institutional license (no. 20/DAF/06, Mayotte Prefecture).

\section{LITERATURE CITED}

Ballorain K, Nivert N (2009) L'évolution statutaire de Mayotte et les enjeux environnementaux: l'exemple de la protection des tortues marines. Revue Juridique de l'Océan Indien 9:107-135

Ballorain K, Ciccione S, Bourjea J, Grizel H, Enstipp M, Georges JY (2010) Habitat use of a multispecific seagrass meadow by green turtles Chelonia mydas at Mayotte Island. Mar Biol 157:2581-2590

Bernardie-Tahir N, Omar EM (2001) Mayotte: des parfums au tourisme. Les nouveaux enjeux du littoral. Cah O M 216:369-396
Biuw M, McConnell B, Bradshaw CJA, Burton H, Fedak MA (2003) Blubber and buoyancy: monitoring the body condition of free-ranging seals using simple dive characteristics. J Exp Biol 206:3405-3423

$>$ Bjorndal KA (1980) Nutrition and grazing behavior of the green turtle, Chelonia mydas. Mar Biol 56:147-154

Bjorndal KA (1997) Foraging ecology and nutrition of sea turtles. In Lutz PL, Musick JA (eds) The biology of sea turtles. CRC Press, Boca Raton, FL, p 199-232

> Blumenthal JM, Austin TJ, Bothwell JB, Broderick AC and others (2009) Diving behavior and movements of juvenile hawksbill turtles Eretmochelys imbricata on a Caribbean coral reef. Coral Reefs 28:55-65

Bograd SJ, Block BA, Costa DP, Godley BJ (2008) Biologging technologies: new tools for conservation. Introduction. Endang Species Res 10:1-7

Bourjea J, Frappier J, Quillard M, Ciccione S, Roos D, Hughes G, Grizel H (2007a) Mayotte Island: another important green turtle nesting site in the southwest Indian Ocean. Endang Species Res 3:273-282

Bourjea J, Lapègue S, Gagnevin L, Broderick D and others (2007b) Phylogeography of the green turtle, Chelonia mydas, in the Southwest Indian Ocean. Mol Ecol 16: 175-186

Brill RW, Balazs GH, Holland KN, Chang RKC, Sullivan S, George JC (1995) Daily movements, habitat use and submergence intervals of normal and tumor-bearing juvenile green turtles (Chelonia mydas L.) within a foraging area in the Hawaiian islands. J Exp Mar Biol Ecol 185: 203-218

Broderick AC, Coyne MS, Fuller WJ, Glen F, Godley BJ (2007) Fidelity and overwintering of sea turtles. Proc R Soc Lond B 274:1533-1538

Burkholder DA (2012) Top down control in a relatively pristine seagrass ecosystem. PhD dissertation, Florida International University, Miami

Buttemer WA, Dawson WR (1993) Temporal pattern of foraging and microhabitat use by Galápagos marine iguanas, Amblyrhynchus cristatus. Oecologia 96:56-64

> Casey J, Garner J, Garner S, Williard AS (2010) Diel foraging behavior of gravid leatherback sea turtles in deep waters of the Caribbean Sea. J Exp Biol 213: 3961-3971

Costa DP, Gales NJ, Goebel ME (2001). Aerobic dive limit: how often does it occur in nature? Comp Biochem Physiol A 129:771-783

> Davis RW, Fuiman LA, Williams TM, Hornin M, Hagey W (2003) Classification of Weddell seal dives based on 3 dimensional movements and video-recorded observations. Mar Ecol Prog Ser 264:109-122

$>$ Duarte CM (1992) Nutrient concentration of aquatic plants: patterns across species. Limnol Oceanogr 37:882-889

Eckert SA, Nellis DW, Eckert KL, Kooyman GL (1986) Diving patterns of two leatherback sea turtles (Dermochelys coriacea) during internesting intervals at Sandy Point, St Croix, US Virgin Islands. Herpetologica 42: 381-388

Enstipp MR, Ciccione S, Gineste B, Milbergue M and others (2011) Energy expenditure of freely swimming adult green turtles (Chelonia mydas) and its link with body acceleration. J Exp Biol 214:4010-4020

> Felger RS, Cliffton K, Regal PJ (1976) Winter dormancy in sea turtles: independent discovery and exploitation in the Gulf of California by two local cultures. Science 191: 283-285 
Fossette S, Ferraroli S, Tanaka H, Ropert-Coudert Y and others (2007) Dispersal and dive patterns in gravid leatherback turtles during the nesting season in French Guiana. Mar Ecol Prog Ser 338:233-247

> Fossette S, Gaspar P, Handrich Y, Le Maho Y, Georges JY (2008) Dive and beak movement patterns in leatherback turtles Dermochelys coriacea during internesting intervals in French Guiana. J Anim Ecol 77:236-246

Fossette S, Girard C, Bastian T, Calmettes B and others (2009) Thermal and trophic habitats of the leatherback turtle during the nesting season in French Guiana. J Exp Mar Biol Ecol 378:8-14

> Fossette S, Gleiss AC, Myers AE, Garner S and others (2010) Behaviour and buoyancy regulation in the deepest diving reptile: the leatherback turtle. J Exp Biol 213: 4074-4083

> Godley BJ, Thompson DR, Waldron S, Furness RW (1998) The trophic status of marine turtles as determined by stable isotope analysis. Mar Ecol Prog Ser 166:277-284

> Godley BJ, Richardson S, Broderick AC, Coyne MS, Glen F, Hays GC (2002) Longterm satellite telemetry of the movements and habitat utilisation by green turtles in the Mediterranean. Ecography 25:352-362

Godley BJ, Blumenthal JM, Broderick AC, Coyne MS, Godfrey MH, Hawkes LA, Witt MJ (2008) Satellite tracking of sea turtles: Where have we been and where do we go next? Endang Species Res 4:3-22

> Hays GC, Adams CR, Broderick AC, Godley BJ, Lucas DJ, Metcalfe JD, Prior AA (2000) The diving behaviour of green turtles at Ascension Island. Anim Behav 59: $577-586$

> Hazel J (2009) Evaluation of fast-acquisition GPS in stationary tests and fine-scale tracking of green turtles. J Exp Mar Biol Ecol 374:58-68

> Hazel J, Lawler IR, Hamann M (2009) Diving at the shallow end: Green turtle behaviour in near-shore foraging habitat. J Exp Mar Biol Ecol 371:84-92

> Heaslip SG, Iverson SJ, Bowen WD, James MC (2012) Jellyfish support sigh energy intake of leatherback sea turtles (Dermochelys coriacea): video evidence from animalborne cameras. PLoS ONE 7:e33259

> Heilman MJ, Spieler RE (1999) The daily feeding rhythm to demand feeders and the effects of timed meal-feeding on the growth of juvenile Florida pompano, Trachinotus carolinus. Aquaculture 180:53-64

> Heithaus MR, Dill LM (2006) Does tiger shark predation risk influence foraging habitat use by bottlenose dolphins at multiple spatial scales? Oikos 114:257-264

Heithaus M, McLash J, Frid A, Dill L, Marshall G (2002) Novel insights into green sea turtle behaviour using animal borne video cameras. J Mar Biol Ass UK 82: 1049-1050

> Hochscheid S, Godley BJ, Broderick AC, Wilson P (1999) Reptilian diving: highly variable dive patterns in the green turtle Chelonia mydas. Mar Ecol Prog Ser 185: 101-112

> Hochscheid S, Bentivegna F, Bradai MN, Hays GC (2007a) Overwintering behaviour in sea turtles: dormancy is optional. Mar Ecol Prog Ser 340:287-298

> Hochscheid S, McMahon CR, Bradshaw CJA, Maffucci F, Bentivegna F, Hays GC (2007b) Allometric scaling of lung volume and its consequences for marine turtle diving performance. Comp Biochem Physiol A 148:360-367

> Hochscheid S, Bentivegna F, Hamza A, Hays GC (2010) When surfacers do not dive: multiple significance of extended surface times in marine turtles. J Exp Biol 213: 1328-1337

Hooker SK, Biuw M, McConnell BJ, Miller PJO, Sparling CE (2007) Bio-logging science: logging and relaying physical and biological data using animal-attached tags. Deep-Sea Res II 54:177-182

> Houghton JDR, Woolmer A, Hays GC (2000) Sea turtle diving and foraging behaviour around the Greek Island of Kefalonia. J Mar Biol Ass UK 80:761-762

> James MC, Myers RA, Ottensmeyer CA (2005) Behaviour of leatherback sea turtles, Dermochelys coriacea, during the migratory cycle. Proc Biol Sci 272:1547-1555

James MC, Ottensmeyer CA, Eckert SA, Myers RA (2006) Changes in diel diving patterns accompany shifts between northern foraging and southward migration in leatherback turtles. Can J Zool 84:754-765

Jonsen ID, Myers RA, James MC (2007) Identifying leatherback turtle foraging behaviour from satellite-telemetry using a switching state-space model. Mar Ecol Prog Ser 337:255-264

Klein W, Perry SF, Abe AS, Andrade DV (2006) Metabolic response to feeding in Tupinambis merianae: circadian rhythm and a possible respiratory constraint. Physiol Biochem Zool 79:593-601

Lesage V, Hammil MO, Kovacs KM (1999) Functional classification of harbor seal (Phoca vitulina) dives using depth profiles, swimming velocity, and an index of foraging success. Can J Zool 77:74-87

Losey GS, Balazs GH, Privitera LA (1994) Cleaning symbiosis between the wrasse, Thalassoma duperry, and the green turtle, Chelonia mydas. Copeia 3:684-690

Makowski C, Seminoff JA, Salmon M (2006) Home range and habitat use of juvenile Atlantic green turtles (Chelonia mydas L.) on shallow reef habitats in Palm Beach, Florida, USA. Mar Biol 148:1167-1179

- McMahon CR, Bradshaw CJA, Hays GC (2007) Satellite tracking reveals unusual diving characteristics for a marine reptile, the olive ridley turtle Lepidochelys olivacea. Mar Ecol Prog Ser 329:239-252

> Mendonca MT (1983) Movements and feeding ecology of immature green turtles (Chelonia mydas) in a Florida lagoon. Copeia 4:1013-1023

Miller JD (1997) Reproduction in sea turtles. In: Lutz PL, Musick JA (eds) The biology of sea turtles. CRC Press, Boca Raton, FL, p 51-81

Minamikawa S, Naito Y, Uchida I (1997) Buoyancy control and diving behaviour of the loggerhead turtle, Caretta caretta. J Ethol 15:109-118

Myers AE, Hays GC (2006) Do leatherback turtles Dermochelys coriacea forage during the breeding season? A combination of novel and traditional data logging devices provide new insights. Mar Ecol Prog Ser 322: 259-267

Nielsen BL (1999) On the interpretation of feeding behaviour measures and the use of feeding rate as an indicator of social constraint. Appl Anim Behav Sci 63:79-91

Ogden JC, Robinson L, Whitlock K, Daganhardt H, Cebula R (1983) Diel foraging patterns in juvenile green turtles (Chelonia mydas L.) in St. Croix United States Virgin Islands. J Exp Mar Biol Ecol 66:199-205

> Okuyama J, Kawabata Y, Naito Y, Arai N, Kobayashi M (2009) Monitoring beak movements with an acceleration datalogger: a useful technique for assessing the feeding and breathing behaviors of sea turtles. Endang Species Res 10:39-45 
Pinheiro J, Bates D, DebRoy S, Sarkar D, the R Development Core Team (2012). nlme: Linear and nonlinear mixed effects models. $\mathrm{R}$ package version 3.1-103.

Rice MR, Balazs GH, Hallacher L, Dudley W, Watson G, Krusell K, Larson B (2000) Diving, basking, and foraging patterns of a sub-adult green turtle at Punalu'u, Hawaii. In: Abreu-Grobois FA, Briseño-Duenas R, MárquezMillán, Sarti-Martinez L (eds) Proc 18th Annu Int Sea Turtle Symp. NOAA Tech Memo NMFS-SEFSC-438, p 229-231

Roos D, Pelletier D, Ciccione S, Taquet M, Hughes G (2005) Aerial and snorkelling census techniques for estimating green turtle abundance on foraging areas: A pilot study in Mayotte Island (Indian Ocean). Aquat Living Resour 18:193-198

Ropert-Coudert Y, Wilson RP (2005) Trends and perspectives in animal-attached remote sensing. Front Ecol Environ 3:437-444

Sapsford CW, Van der Riet M (1979) Uptake of solar radiation by the sea turtle, Caretta caretta, during voluntary basking. Comp Biochem Physiol A 63:471-474

Sato K, Mitani Y, Cameron MF, Siniff DB, Watanabe Y, Naito $Y$ (2002) Deep foraging dives in relation to the energy depletion of Weddell seal (Leptonychotes weddellii) mothers during lactation. Polar Biol 25:696-702

Schofield G, Katselidis KA, Dimopoulos P, Pantis JD, Hays GC (2006) Behaviour analysis of the loggerhead sea turtle Caretta caretta from direct in-water observation. Endang Species Res 2:71-79

Seebacher F, Franklin CE (2005) Physiological mechanisms of thermoregulation in reptiles: a review. J Comp Physiol B 175:533-541

Seminoff JA, Resendiz A, Nichols WJ (2002) Home range of green turtles Chelonia mydas at a coastal foraging area in the Gulf of California, Mexico. Mar Ecol Prog Ser 242: 253-265

Seminoff JA, Jones TT, Marshall GJ (2006) Underwater behaviour of green turtles monitored with video-timedepth recorders: what's missing from dive profiles? Mar Ecol Prog Ser 322:269-280

Southwood AL, Reina RD, Jones VS, Jones DR (2003) Seasonal diving patterns and body temperatures of juvenile green turtles at Heron Island, Australia. Can J Zool 81: 1014-1024

Sparling CE, Georges JY, Gallon SL, Fedak MA, Thompson D (2007) How long does a dive last? Foraging decisions by breath hold divers in a patchy environment - a test of a simple model. Anim Behav 74:207-218

Spotila JR, O'Connor MP, Paladino FV (1997) Thermal biology. In: Lutz PL, Musick JA (eds) The biology of sea turtles. CRC Press, Boca Raton, FL, p 297-314

Stephens DW, Krebs JR (1986) Foraging theory. Princeton University Press, Princeton, NJ

Takahashi A, Kokubun N, Mori Y, Shin HC (2008) Krill-

Editorial responsibility: Hans Heinrich Janssen,

Oldendorf/Luhe, Germany feeding behaviour of gentoo penguins as shown by animal-borne camera loggers. Polar Biol 31:1291-1294

- Taquet C, Taquet M, Dempster T, Soria M, Ciccione S, Roos D, Dagorn L (2006) Foraging rhythms of the green sea turtle Chelonia mydas on seagrass beds in N'Gouja Bay, Mayotte (Indian Ocean), determined by acoustic transmitters and listening station. Mar Ecol Prog Ser 306: 295-302

Thomson JA, Burkholder DA, Cooper AB, Heithaus MR, Dill LM (2012) Heterogeneous patterns of availability for detection during visual surveys: spatiotemporal variation in sea turtle dive-surfacing behaviour on a feeding ground. Methods Ecol Evol 3:378-387

Thums M, Bradshaw CJA, Hindell MA (2008) A validated approach for supervised dive classification in diving vertebrates. J Exp Mar Biol Ecol 363:75-83

> van Dam RP, Diez CE (1997) Diving behavior of immature hawksbill turtles (Eretmochelys imbricata) in a caribbean reef habitat. Coral Reefs 16:133-138

> Wallace BP, Jones TT (2008) What makes marine turtles go: a review of metabolic rates and their consequences. J Exp Mar Biol Ecol 356:8-24

- Wallace BP, Williams CL, Paladino FV, Morreale SJ, Lindstrom RT, Spotila JR (2005) Bioenergetics and diving activity of internesting leatherback turtles Dermochelys coriacea at Parque Nacional Marino Las Baulas, Costa Rica. J Exp Biol 208:3873-3884

> Ward A, Liu J, Feng Z, Xu XZS (2008) Light-sensitive neurons and channels mediate phototaxis in C. Elegans. Nat Neurosci 11:916-922

Whittow GC, Balazs GH (1982) Basking behavior of the Hawaiian green turtle (Chelonia mydas). Pac Sci 36:129-139

Wikelski M, Hau M (1995) Is there an endogenous tidal foraging rhythm in marine iguanas? J Biol Rhythms 10: 335-350

> Williams SL (1988) Thalassia testudinum productivity and grazing by green turtles in a highly disturbed seagrass bed. Mar Biol 98:447-455

Wilson RP (2003) Penguins predict their performance. Mar Ecol Prog Ser 249:305-310

Wilson RP, Quintana F (2004) Surface pauses in relation to dive duration in imperial cormorants; how much time for a breather? J Exp Biol 207:1789-1796

Witt MJ, Åkesson S, Broderick AC, Coyne MS, and others (2010a) Assessing accuracy and utility of satellitetracking data using Argos-linked Fastloc-GPS. Anim Behav 80:571-581

> Witt MJ, McGowan A, Blumenthal JM, Broderick AC and others (2010b) Inferring vertical and horizontal movements of juvenile marine turtles from time-depth recorders. Aquat Biol 8:169-177

Zoufal R, Taborsky M (1991) Fish foraging periodicity correlates with daily changes of diet quality. Mar Biol 108: 193-196

Submitted: November 5, 2010; Accepted: February 5, 2013

Proofs received from author(s): May 11, 2013 